\title{
Forming a Well Organized Writing Activities
}

\author{
Irfan Tosuncuoğlu \\ Correspondence: Irfan Tosuncuoğlu, Karabuk University, Faculty of Letters, English Language and Literature \\ Department, Karabuk, 78050, Turkey.
}

\author{
Received: March 25, 2018 \\ Accepted: April 19, $2018 \quad$ Online Published: May 2, 2018 \\ doi:10.11114/jets.v6i6.3111 \\ URL: https://doi.org/10.11114/jets.v6i6.3111
}

\begin{abstract}
English has been widely spoken in the world and seen as the language of education, communication, economics and etc., for a long time and it can be accepted as lingua franca. Knowledge of a language includes four basic language skills, these are listening, reading, speaking, and writing. In this study writing was investigated in detail and it was mentioned why writing was difficult and importance of writing was explained. This study was produced from the author's doctoral dissertation. It was seen that students' ability to write in a well- organized manner was insufficient. So, in the study, the main components for a well-organized composition that is outlining, coherence, unity were explained. In addition remedial exercises for developing writing skills were indicated in order to develop students' writing skills. In the research, controlled pre, post-test Experimental Design was used. During the pedagogical experiment the teacherexperimentator himself carried out all the studies in control and experimental groups during the process of the experiment. Furthermore it was stressed that materials and teachers skills were important for the development of the students in the related topic.
\end{abstract}

Keywords: English, writing, language, outlining, coherence, unity

\section{Introduction}

English has been widely spoken internationally for years all around the globe and it is considered to be a lingua-franca which was reflected in the studies of English Language Teaching (ELT) since the years of 2000 (Waters, 2012). That is to say that English has been seen as the language of education, communication economics and etc. It can also be seen as the dominant and language in the world. Moreover Seidlhofer (2005) says that, it cannot be refused that English functions as a lingua franca and bearing this fact in mind, attention and focus amongst people about English has been raised and thus generated motivation to learn and to teach the language.

According to Brown (2000) and Nunan (1989), the language was known to include four basic language skills, these are listening, reading, speaking, and writing). Listening and reading skills are perceptive (decoding) skills that involve the language- learner, it is to guess the meaning from the discourse, and the latter two are productive (encoding) skills that learners have to produce language on their own (Harmer, 2007). In the process of perceptive skills, students are exposed to input by some sources of information such as teachers, TV, noticeboards, so on and so forth. In productive skills students' lexicon (decoding) is activated during the production process of the activity.

\subsection{Difficulty of Writing}

Speaking and Writing skills are considered as a productive action, and speaking and writing have much in common. However they differ from each other to some extent. Many sources claim the difference as in a number of ways:

-writing is a relatively recent development in human societies

-we speak a great deal more than we write

-we acquire speaking without conscious effort, but writing is usually less spontaneous and less automatic, it requires some rules (ortography, punctuantion, etc.) and serious background.

Kroll (2001) says that writing is a skill which must be deliberately taught and requires practice to be developed. Gabrielatos et al. (2002; cited in Öğüten, 2009), expressed that "writing is a complex skill, and its development involves much more than the accurate use of grammar and a good range of vocabulary. A comprehensive EFL writing program requires the systematic treatment of a large number of interrelated elements".

As writing allows writers to explore feelings, ideas and thoughts, it is considered as a complex and hard process. For 
English learners as Foreign or Secondary Language learners, it is a fact that writing is a very difficult task because it forces the learners' feelings ideas and thoughts to concentrate which involves great effort, skill and ability. To write effectively, it is needed to take many things into mind in pre, while, and post writing.

\subsection{Importance of Writing}

Writing as an activity and practice is not just words put together, but it is something that enables human intellect and capabilities to be visible, (Dooley, 1995). For many cultures, writing represents a high status and means being educated. Writers are privileged and respected, as well, (Leki, 1992).Writing is an important skill for both first and second language and it is not a skill which is naturally learned like walking (Lenneberg, 1967; cited in Brown, 2001).

Furthermore, the importance given to writing has increased as the features of communicative language teaching have been dominating in both foreign and second language contents. Writing was gradually recognized as a process of thinking and composing as a result of communicative language teaching. Writing has been regarded as an important "enterprise in and of itself in contrary to the traditional view which considers that writing functions to support and consolidate oral language use, grammar and vocabulary" (Weigle, 2002).

To sum up a writer conveys his/ her ideas through writing and tells the reader what he wants to infer. Writing requires cultural and linguistic knowledge. Writing being one of the language skills as seen above, is an important part in foreign language learning. It is important for all the students study for all institutions, for communicative purposes since writing is written interaction, that is, the written way of communication. It is obvious that such a writing process can also help students to reach a proficiency level, at which they can use a foreign language. Writing becoming more and more important because writing helps students learn the target language and provide them with opportunities to practice it. Writing can stimulate every individual's cultural background, and contribute to previous knowledge. In addition, it awakens the interest of learning more through challenging or enjoyable topics.

\section{Problem}

Analysis of students of English classes at schools in Bishkek, Kyrgyzstan, though they have good knowledge in grammar, they have difficulties in expressing their ideas in English. They can not create well organized and coherent texts in English Courses. Parallel to this, in language training, writing is one of the most difficult tasks and includes several skills: spelling, usage of grammar, vocabulary, organization of lexis, etc. Traditionally, writing is based on what has been learnt; repetition of grammar, spelling, word choice etc. Corbett (1965) explains traditional writing as "an emphasis on correct usage of grammar and spelling“. For Zamel (1976) "grammar instruction might have harmful effects on writing". According to Sharwood-Smith (1974) "grammar is probably not a useful unit for teaching writing, even though so many drills and exercises are based on it". But the content is more important than the grammar, spelling and punctuation in written speech. As it has been seen, to teach to know all the grammatical rules and spelling is not enough for writing. On the other hand Kırmızı and Kırmızı (2015), say that it is almost imperative in the teaching of the writing skill to ensure the cognitive, behavioral and motivational engagement of students, which is facilitated by increased writing self-efficacy.

The main aim and objective of a writing class is to include learners' into writing activities actively and to help them create satisfactory writing skills. In order to realize this target, writing activities and material choosing must be given importance. That is to say that, writing activities are more important than grammar, it is not a kind of activity to practice grammar or vocabulary within the curriculum.

\subsection{Organization of a Good Writing}

While analyzing students' written works we noticed that they could not organize material in their compositions. Textbooks used in schools, Kyrgyzstan had no exercises for teaching organization of the materials (both in oral iand written forms). As the result of investigation of the linguo-methodological literature; Adıgüzel (1988), Yildırım (1991), helped us to reach the conclusion that to teach skills of organizing ideas in a written form can be achieved by teaching three main qualities of the text: 1) Outlining, 2) Coherence and 3)Unity. Each element of the things above pays attention to the well organization of the text.

\subsubsection{Outline}

Outlining is used in activities concerned with reading and writing tasks, it is a useful language skill for everyone to learn. Simply, an outline is basically an organized list of expression ideas, thoughts and items. It is a style of grouping together or selecting similar things, then listing or presenting them in a manner that clearly shows or denotes the relationship them within each group or all the groups. Reid indicates that (1984), "student writers sometimes have difficulty organizing the material they have gathered for a composition. One way to order your ideas is outlining". And Frank (1980) says, "constant use of an outline makes students aware of the need for their composition." 
Consequently, in writing it is very important to construct a good outline, which requires logical coordination, and grammatic parallelism.

\subsubsection{Coherence}

The second very important skill for achieving good-organization in writings is Coherence. It can be basically described as logical and orderly arrangement of all the ideas. According to Gallo (1973), "Coherence is the glue that joins the ideas together". Moreover, Blass and Durighello (1985) denote about coherence that, "Coherence allows the reader to follow the writer's thoughts through a logical series of sentences and paragraphs".

So, the sentences in the paragraphs must be clearly related to each other. One sentence should lead into the next, one idea should follow another coherently so that the reader is carried forward without confusion, the clear connection between statements comes first. In Coherence, the right connective is very important to sentence meaning. Variety in the usage of connectives leads to more effective expression, choosing the right conjunction is essential for conveying meaning accurately. And the other point for coherent writing is that the students should write conjunctions and phrases when needed.

\subsubsection{Unity}

The third and final important concept for achieving good organization is Unity. Oshima and Hogue (1981) indicate that, "when we talk about paragraph unity we mean that you should discuss only one main idea in each paragraph" and Eells (1942) says that by unity it is meant that each paragraph should have one central and main idea.

According to Bander (1985), "A paragraph which has all its sentences focusing on one idea is said to have unity." That is, if the dominating idea can cover the whole composition it can be said that it has unity. The main or dominating idea can be defined as a controlling idea that tells what the main subject of a paragraph or composition will be and indicates how the paragraph or composition will be developed.

Although there are different arguments and opinions about the desirable location of the topic sentence in a paragraph, writers can have various preferences, according to the purpose of the piece they intended to write. As has been emphasized above, the topic sentence, controlling idea, and minor and major support sentences, are fundamental elements for unity in a paragraph or a composition.

\section{Method}

In the research, controlled pre, post-test Experimental Design was used. During the pedagogical experiment the teacher -experimentator himself carried out all the studies in control and experimental groups during the process of the experiment.

Two kinds of tests were suggested during the experiment: pre-test and post-test. By means of the scoring table, students' pre and post-test results, were assessed. Then, success percentage was obtained by means of the following formula by Usova, (1988).

$$
C_{c}=\frac{1}{n \cdot N} \cdot \sum_{i=1}^{N} \cdot n_{i}
$$

$\mathrm{C}_{\mathrm{C}}$ : coefficient completeness ability of the Control Group

$\mathrm{N}$ : number of the students

$\mathrm{n}_{\mathrm{i}}$ : number of marks more than 50

$\mathrm{n}$ : maximum mark

\subsection{Methods of Work in the Control and Experimental Groups}

\section{Control Group}

During the experiment, the textbooks of English according to schools and grades were used for the students in the control groups. The speech models and the textbooks' exercises were the material for writing. Written work was given as homework from their books.

\section{Experimental Group}

Teaching of written speech in experimental groups was fulfilled in the same way as in the control groups (the same textbooks). Besides about more than 60 supplementary exercises was used in order to develop the skills in the field of well-organized writing, for the students in experimental group. Such as;

Exercise 1: Work with your partners. Organize the following food into three main groups. Each group should 
include only that food, which is similar to each other. Discuss them with your friends and then write on the lines.

$\begin{array}{lcll}\begin{array}{l}\text { beef } \\ \text { spinach }\end{array} & \begin{array}{l}\text { potatoes } \\ \text { banana } \\ \text { eggplant }\end{array} & \begin{array}{l}\text { mutton } \\ \text { beet } \\ \text { lamb }\end{array} & \begin{array}{l}\text { leek } \\ \text { peaches } \\ \text { pork }\end{array} \\ \text { Meat } & \text { Fruit } & & \text { Vegetable } \\ \ldots \ldots \ldots & \ldots \ldots \ldots . & \ldots \ldots \ldots \\ \ldots \ldots \ldots & \ldots \ldots \ldots . & \ldots \ldots \ldots \\ \ldots \ldots \ldots & \ldots \ldots \ldots . . & \ldots \ldots \ldots\end{array}$

Exercise 2: Work in pairs. Read the passage below and discuss it, then complete the skeleton of the given outline.

Many insects are harmful while others are helpful. Some insects destroy plants and trees. Some destroy stored grain, flour and meal. Some attack clothing and carpets. Others cause discomfort to animals by boring into their skin, biting and stinging. On the other hand, many insects help us indirectly. Some eat harmful larvae. Others help to prevent the spread of decay by eating rotting wood and plants.

Insects

A.

1. Destroy

a. ...............

b.

2.

a.

b.

$$
\text { c. }
$$

3.
a.
b.
(c. ..............)

4.

a.

b.

B.

1.

2. help to prevent the spread of decay by eating.

a.

b.

C.

1.Destroy plants and trees

2.

3.

4.

D. Helpful

1.

2 . 
Exercise 3: Work in pairs. Select one of these topics and write a paragraph. Then discuss your ideas with your partner.

1. Write about a famous sportsman or woman in your country. Tell us about this person and why s/he is so famous.

2. Do you have a favorite sport? Describe and explain why you enjoy it.

Exercises are divided into three main groups; outline, coherence, unity.

\section{Results and Discussion}

As it was aforementioned, a well -organized piece of writing requires three items, that is, outline, coherence and unity. Materials and exercises to teach writing, indeed, are very important, concerning this as teachers we have big responsibilities. If teachers want to support writing as a skill in a foreign language, they should go beyond writing for learning and encourage their students to write for writing as stated by Harmer (2007). This article basically attempted to explore the result of suggested more than 60 exercises applied to the students in the experiment period. These exercises consisted of three important requirements in a well-organized piece of writing. The aim of the so called exercises is to make students communicate their ideas in examinations, reports, etc. With the help of these exercises forming of the following abilities were meant:

-to describe successively events in chronological order;

-to choose main facts while describing things, characters and places;

-to establish casual relations in acts and events;

-to form conclusions, summaries etc.

Analyzing the level of students' knowledge and skills after the experiment period by means of aforementioned formula, it can be concluded that although they had no abilities producing well organized and coherent speech (both in oral and in written form) before the experiment, through the application of additional exercises during the experiment, students' skills in experimental group, in writing, developed to some extent.

\section{References}

Adıgüzel, M. F. (1988). The Effects of the Process Approach to Teaching Writing on Turkish Students' Writing Skills, and Overall Language Proficiency in EFL.Unpublished Master Thesis, Mersin Üniversitesi, Mersin.

Bander, R. G. (1985) From Sentence to Paragraph: A Writing book. -New York: CBS college publishing.

Blass, L., \& Durighello, J. (1985). From Concept to Composition. -New Jersey: Prentice Hall, Inc., Englewood Cliffs.

Brown, H. D. (2000). Teaching by Principles: An Interactive Approach to Language Pedagogy, Pearson Education, Longman

Brown, H. D. (2001). Teaching by Principles: An Interactive Approach to Language Pedagogy. White Plains, NY: Longman

Corbett, E. P. (1965). Classical Rhetoric for Modern Student. New York: Oxford University Press.

Dooley, D. A. (1995). Plain and Ordinary Things: Reading Women in the Writing Classroom, Albany

Eells, H. (1942). Writing Thesis. Edinburgh: The Antioch press, 12-14.

Frank, M. (1980). A New Approach to Guided Composition for Intermediate Students. Washington D.C.: International Communication Agency.

Gabrielatos, C. (1998-2002). EFL Writing Product and Process, Website, http://www.gabrielatos.com/EFLWriting.htm

Gallo, D. J. (1973). Shaping College Writing. -New York: Harcourt Brace Jovanich Inc., 58-59.

Harmer, J. (2007). The Practice of English Language Teaching. Harlow: Longman.

Kırmızı, Ö., \& Kırmızı, G. D. (2015). An Investigation of L2 Learners' Writing Self-Efficacy, Writing Anxiety and Its Causes at Higher Education in Turkey. International Journal of Higher Education, 4(2). https://doi.org/10.5430/ijhe.v4n2p57

Kroll, B. (2001). Second Language Writing, Cambridge, New York.

Leki, I. (1992). Understanding ESL Writers. Portsmouth: Boyton, Cook Publishers.

Lenneberg, E. H. (1967). New Ways in Teaching Adults. In H. Douglas Brown 2001. Teaching by Principles: An Interactive Approach to Language Pedagogy. White Plains, NY: Longman.

Nunan, D. (1989). Designing Tasks for the Communicative Classroom. Cambridge University Press. 
Öğüten, S. D. (2009). The use of Writing Portfolioin Preparatory Writing Classes to Foster Learner Autonomy. Unpublished Doctoral Thersis, Cukurova University

Oshima, A., \& Hogue, A. (1981). Writing Academic English. Addison: Wesley Publishing Company, 17-19.

Reid, M. J. (1984). The Process of Composition. 2nd ed., New Jersey: Prentice Hall Regents Englewood Cliffs, 235.

Seidlhofer, B. (2005). English as a Lingua Franca. ELT journal, 59(4), 339. https://doi.org/10.1093/elt/cci064

Sharwood-Smith, M. (1974). Teaching Written English: Problems and Principles. English Teaching Forum. Washington D.C., 12(3), 8-12.

Usova, A. V. (1988). Psychological and Didactical Basis for the Formation of Physical Concepts. Chelyabinsk, Russia: Chelyabinsk State Pedagogical Institute.

Waters, A. (2012). Trends and Issues in ELT Methods and Methodology. ELT Journal, 66(4). https://doi.org/10.1093/elt/ccs038

Weigle, C. S. (2002). Assessing Writing. Cambridge University Press, Newyork. https://doi.org/10.1017/CBO9780511732997

Yıldırım, R. (1991). Improving Writing Skills in Large Classes in High Schools through Group and Pair Work. Unpublished master thesis, Çukurova University.

Zamel, V. (1976). Teaching Composition in the ESL Classroom: What We can Learn from Research in the Teaching of English.//TESOL Quarterly. Boston: Halliday Inc., 14, 81-90. https://doi.org/10.2307/3585940

\section{Copyrights}

Copyright for this article is retained by the author(s), with first publication rights granted to the journal.

This is an open-access article distributed under the terms and conditions of the Creative Commons Attribution license which permits unrestricted use, distribution, and reproduction in any medium, provided the original work is properly cited. 